\title{
OPTIMALISASI DAKWAH MELALUI MEDIA SOSIAL DI ERA MILENIAL
}

\author{
Muhammad Habibi \\ Jurusan Komunikasi Penyiaran Islam (J-KPI) \\ Fakultas Ushuluddin, Adab, dan Dakwah (FUAD) \\ Institut Agama Islam Negeri (IAIN) Pontianak \\ Email: abigus14@gmail.com
}

\begin{abstract}
Social media is a trend among millennial generation. Da'wah must make the most of it. Otherwise, the flow of da'wah is slowing down and lagging behind. This article discuss the impact of globalize information which is characterized by the advancement of communication technology, associated with da'i readiness in using it in delivering da'wah. How to optimize social media for da'wah? Through literature studies it can be explained that the optimization of da'wah through social media can be carried out with viral communication techniques and attractive content packaging by utilizing interactive social media.

(Media sosial menjadi tren di kalangan generasi milenial. Dakwah harus memanfaatkannya semaksimal mungkin. Jika tidak, arus dakwah kian melambat dan tertinggal. Artikel ini mendiskusikan dampak globalisasi informasi yang ditandai dengan kemajuan teknologi komunikasi, dikaitkan dengan kesiapan dai dalam memanfaatkannya dalam menyampaikan dakwah. Bagaimana mengoptimalkan media sosial untuk dakwah? Melalui studi literatur dapat dijelaskan bahwa optimalisasi dakwah melalui media sosial dapat dilakukan dengan teknik komunikasi viral dan pengemasan konten yang menarik dengan memanfaatkan media sosial yang sifatnya interaktif).
\end{abstract}

Kata Kunci: dakwah, media, milenial

\section{PENDAHULUAN}

Dakwah pada era milenial benar-benar harus memanfaatkan media, utamanya media-media baru. Perkembangan teknologi komunikasi telah mengubah cara orang berkomunikasi. Saat ini, hampir setiap orang menggunakan internet dalam mengirim, mencari, dan membaca informasi. Dalam berinteraksi pun kebanyakan melalui media sosial dibanding komunikasi secara langsung. Hal ini sangat dimungkinkan terjadi setidaknya dipengaruhi beberapa faktor, antara lain pesatnya perkembangan teknologi informasi dan komunikasi, juga kecenderungan masyarakat milenial yang sangat bergantung pada media. Kaitannya dengan dakwah, peran media sangat strategis dalam upaya penyampaian pesan dakwah. Media mampu menembus batasbatas ruang dan waktu. Artinya, meski dengan jarak jauh komunikasi memungkinkan dilakukan. Tidak hanya itu, media juga menawarkan kecepatan 
waktu dalam menyediakan beragam informasi.

Media saat ini tumbuh kian pesat. Dulu, media elektronik seperti televisi dan radio menjadi pilihan favorit dalam mencari informasi. Keunggulannya adalah mampu mengirim pesan suara dan gambar (visual). Saat ini realita itu mulai bergeser. Publik tidak lagi berpusat pada media elektronik sebagai sumber informasi. Justru, kegandrungannya saat ini beralih ke new media (internet).

Perkembangan media baru sebenarnya merujuk pada perubahan dalam proses produksi media, distribusi, dan penggunaan. Media baru tidak terlepas dari aspek digitality, interactivity, hypertextuality, dispersal dan virtuality ${ }^{l}$. Dalam konsep digitality semua proses media digital diubah (disimpan) ke dalam bilangan, sehingga keluarannya (output) dalam bentuk sumber online, digital disk, atau memory drives yang akan diubah dan diterima dalam layar monitor atau dalam bentuk 'hardcopy'. Konsep Interactivity merujuk kepada adanya kesempatan di mana teks dalam media baru mampu memberikan users untuk 'write back into the text'. Sedangkan konsep dispersal media baru lebih kepada proses produksi dan distribusi media menjadi decentralised

\footnotetext{
${ }^{1}$ Martin Lister. New Media: A Critical Introduction, Routledge, London, 2003, hlm. 13.
}

dan mengandalkan keaktifan individu (highly individuated). Batasan new media sering disamakan dengan digital media, yang semestinya new media lebih pada konteks dan konsep budaya kontemporer dari parktik media dari pada seperangkat teknologi itu sendiri (medium).

New media merupakan media yang dapat meningkatkan interaksi sosial antar manusia contohnya melalui beberapa jejaring sosial namun tetap sesuai kaidah dan norma kesopan-santunan Media baru yang saat ini sedang populer adalah handphone atau smartphone.

Zaman sekarang, bagi sebagian besar masyarakat handphone adalah suatu kebutuhan yang sangat penting bahkan sangat diperlukan. karena semakin berkembangnya teknologi handphone tidak hanya digunakan untuk media komunikasi saja seperti sms atau telpon saja. Sekarang banyak handphone yang menyediakan fitur-fitur untuk browsing, chatting dan lain-lain.

New Media merupakan perkembangan baru dari media-media yang telah digunakan manusia. Karakternya yang merupakan bentuk digital tentu memudahkan dalam bertukar informasi dan berbagai kegiatan lainnya.

Era milenial menuntut kecepatan dan kemudahan dalam mengakses informasi. Sementara dakwah belum 
[P. IDI-116]

seutuhnya memanfaatkan ragam media yang terus berkembang. Untuk itu, perlu optimalisasi komunikasi dakwah melalui pemanfaatan media baru (new media), utamanya media sosial, mengingat segmentasi mad'u sangat komplek jika ditinjau dari berbagai sisi. Tulisan ini dimaksudkan untuk mengkaji bagaimana mengoptimalkan komunikasi dakwah melalui media sosial dengan cara memanfaatkan fitur-fitur yang ditawarkan.

Berdasarkan latar belakang di atas dapat diidentifikasi dua permasalahan utama. Pertama, tantangan dakwah semakin kompleks menghadapi era perkembangan teknologi; Kedua, karakteristik masyarakat milenial yang identik dengan kecenderungannya terhadap media sosial. Berdasarkan permasalahan tersebut, maka dirumuskan masalah yang akan dikaji, yaitu "bagaimana mengoptimalkan penyampaian pesan-pesan dakwah kepada masyarakat milenial melalui media sosial".

Tujuan dari kajian ini adalah untuk menemukan langkah-langkah strategis guna mengoptimalkan dakwah. Hasil kajian ini diharapkan berguna untuk pengembangan ilmu komunikasi dan dakwah. Juga, menawarkan solusi yang dapat diimplementasikan untuk mendukung optimalisasi penyampaian pesanpesan dakwah.

\section{Metodologi}

Artikel ini disusun dengan pendekatan studi literatur dengan melakukan kajian pustaka dan menghimpun data dari berbagai sumber seperti jurnal, buku dokumentasi, literatur, dan internet, serta dilanjutkan dengan mencari referensi teori yang relevan dengan permasalahan yang ditemukan. Selanjutnya, data dianalisis secara deskriptif dengan mengemukakan fakta-fakta atau temuan yang kemudian ditinjau secara teoritis.

\section{Dakwah: Tinjauan Umum}

Dakwah secara etimologis berasal dari kata daa'a yad'u dari bahasa Arab berarti memanggil, mengundang, mengajak, menyeru, mendorong, dan memohon. ${ }^{2}$ Secara terminologi, dakwah adalah ajakan, baik berbentuk lisan, tulisan, tingkah laku dan sebagainya, yang dilakukan secara sadar dan berencana dalam usaha mempengaruhi orang lain secara individu maupun kelompok agar timbul dalam dirinya satu pengertian, kesadaran sikap penghayatan serta pengalaman terhadap pengajaran agama sebagai message yang disampaikan kepadanya tanpa adanya unsur paksaan. ${ }^{3}$

${ }^{2}$ Siti Muriah, Metodologi Dakwah Kontemporer, Mitra Pustaka, Yogyakarta, 2000, hlm. 1.

${ }^{3}$ Arifin, Psikologi Dakwah Islam, Bumi Aksara, Jakarta, 1997, hlm. 6. 
Kegiatan dakwah ini antara lain didasarkan pada Alquran surah an-Nahl ayat 125 :

"Serulah (manusia) kepada jalan Tuhanmu dengan hikmahdan pelajaran yang baik dan bantahlah mereka dengan carayang baik.Sesungguhnya Tuhanmu Dialah yang lebih mengetahui tentang siapa yang tersesat dari jalan-Nya dan Dialah yang lebih mengetahui orang-orang yang mendapat petunjuk".

Jika ditinjau dari perspektif ilmu komunikasi, maka dakwah termasuk ke dalam komunikasi persuasif karena komunikasi yang dilakukan bertujuan untuk mengubah atau mempengaruhi kepercayaan, sikap, perilaku seseorang sehingga bertindak sesuai apa yang diharapkan oleh komunikator.

Ada beberapa unsur atau komponen dalam dakwah. Pertama, da'i atau subjek dakwah. Dai adalah pelaksana kegiatan dakwah, baik secara perorangan individual maupun secara bersama-sama secara terorganisasi (Aminudin, 1985:40). Setiap pribadi muslim sesungguhnya adalah dai yang berkewajiban menyampaikan ajaran Islam, walaupun yang disampaikan hanya satu ayat, sebagaimana pesan Nabi dalam haditsnya. Sedangkan untuk menjadi dai profesional yang dapat memberi solusi sesuai dengan tuntutan perkembangan zaman menurut Aziz harus memenuhi kriteria tertentu, yaitu: medalamiAlquran dan hadis, memahami kondisi mad'u, berani mengungkap kebenaran, ikhlas melaksanakan tugas dakwah tanpa tergiur nikmat materi yang hanya bersifat sementara, satu kata dengan perbuatan, serta jauh dari hal-hal yang dapat menjatuhkan harga diri.

Unsur kedua dari dakwah adalah mad'u, objek atau sasaran dakwah. Mad'u adalah penerima dakwah baik secara individu maupun kelompok, muslim maupun non muslim. ${ }^{4}$ Ketiga, metode dakwah. Metode dakwah adalah cara-cara tertentu yang digunakan dai dalam menyampaikan pesan dakwah. Pesan dakwah akan diterima dengan baik apabila menggunakan metode yang tepat dan disesuaikan dengan karakteristik mad'u. Ada beberapa metode yang dapat digunakan, yaitu menyampaikan secara lisan (langsung), tulisan (bi al-qalam), perbuatan (haal), home visit (silaturrahim), infiltrasi (sisipan), drama, dan sebagainya.

Keempat, materi dakwah (maddah). Materi dakwah berisi pesan-pesan ajaran Islam agar diketahui, dipahami, dan diamalkan sebagai pedoman hidup. ${ }^{5}$ Secara umum, materi dakwah dapat diklasifikasi menjadi tiga topik pokok, yaitu tentang

\footnotetext{
${ }^{4}$ Moh. Ali Aziz, Ilmu Dakwah, Kencana, Jakarta, 2004, hlm. 87.

${ }^{5}$ M. Aminudin Sanwar, Pengantar Studi Ilmu Dakwah, Fakultas Dakwah IAIN Walisongo, Semarang, 1985, hlm. 74.
} 
[P. IDI-116]

akidah, syari'ah, dan akhlak yang semuanya bersumber pada Alquran dan hadis. Kelima, media (wasilah). Untuk sampainya pesan kepada mad'u dibutuhkan media yang sesuai dengan situasi dan kondisi. Media adalah alat yang digunakan untum menyampaikan materi dakwah. Ada beberapa bentuk media yang biasa digunakan, antara lain: media lisan (langsung), tulisan (cetak), elektronik (audio, visual), dan yang terbaru adalah new media (internet).

\section{Optimalisasi Dakwah}

Optimalisasi berasal dari kata optimal artinya terbaik atau tertinggi. Mengoptimalkan berarti menjadikan paling baik atau paling tinggi. Sedangkan optimalisasi adalah proses mengoptimalkan sesuatu atau proses menjadikan sesuatu menjadi paling tinggi. ${ }^{6}$ Dalam konteks kajian ini, optimalisasi yang dimaksud adalah upaya, langkah, atau metode yang digunakan untuk mengoptimalkan penyampaian dakwah sehingga dapat diterima lebih luas dan cepat. Dengan optimalisasi dakwah dapat ditingkatkan efektifitasnya, baik dari sisi waktu, biaya, maupun prosesnya.

Langkah optimalisasinya dapat dilakukan dengan memanfaatkan teknologi

${ }^{6}$ Diakses dari https://kbbi.web.id/optimal, pada 8 Oktober 2018 pukul 23.26. informasi dan komunikasi. Dakwah dan teknologi adalah sesuatu yang tidak dapat dipisahkan. Ini jika berpijak pada konsep dakwah kontemporer yang mudah diterima oleh masyarakat kini.

\section{Media Sosial}

Media sosial adalah aplikasi berbasis internet (media online) yang penggunanya bisa membuat web page pribadi, kemudian dapat saling terhubung berbagi informasi dan berkomunikasi. Blog dan jejaring sosial merupakan bentuk media sosial yang paling umum digunakan oleh masyarakat di seluruh dunia. Media sosial mendukung interaksi sosial dan media sosial menggunakan teknologi berbasis web yang mengubah komunikasi menjadi dialog interaktif. Media sosial memiliki ciri-ciri antara lain: pesan yang disampaikan tidak hanya untuk satu orang saja, namun bisa untuk banyak orang; pesan yang disampaikan bebas, tanpa harus melalui gate keeper; pesan yang disampaikan cenderung lebih cepat dibanding media lainnya; dan penerima pesan yang menentukan waktu interaksi.

Perkembangan media sosial kini semakin pesat. Hampir setiap orang memiliki akun media sosial. Hal ini karena dapat diakses kapanpun dan dimanapun tanpa harus mengeluarkan banyak biaya. Cukup menggunakan mobilephone yang 
dikoneksikan pada jaringan internet. Jika untuk memiliki media tradisional seperti televisi, radio, atau Koran dibutuhkan modal yang besar dan tenaga kerja yang banyak, maka lain halnya dengan media sosial. Seorang pengguna media sosial bisa mengakses menggunakan media sosial dengan jaringan internet bahkan yang aksesnya lambat sekalipun, tanpa biaya besar, tanpa alat mahal dan dilakukan sendiri tanpa bantuan yang lain. Pengguna media sosial dengan bebas bisa mengedit, menambahkan, memodifikasi baik tulisan, gambar, video, grafis, dan berbagai model content lainnya.

Berbicara mengenai media sosial tidak terlepas dari kelebihannya dalam fasilitasi membagi ide, bekerja sama, dan membangun komunitas. Selain kecepatan informasi yang bisa diakses dalam hitungan detik, menjadi diri sendiri dalam media sosial adalah alasan mengapa media sosial berkembang pesat. Tidak terkecuali, keinginan untuk aktualisasi diri dan kebutuhan menciptakan personal branding.

Media sosial adalah adalah sarana yang dibuat untuk memudahkan interaksi sosial dan komunikasi dua arah. Dengan semua kemudahan yang diberikan oleh media sosial ini, penyebaran informasi dari satu individu ke individu lain menjadi sangat mudah. ${ }^{7}$ Dengan demikian, media sosial adalah media online yang penggunanya dapat saling berpartisipasi melalui blog, jejaring sosial, forum dan dunia virtual. Blog dan jejaring sosial merupakan bentuk media sosial yang paling umum digunakan oleh masyarakat di seluruh dunia. Media sosial digunakan untuk bersosialisasi satu sama lain dan dilakukan secara online yang memungkinkan manusia saling berinteraksi tanpa dibatasi ruang dan waktu.

Media sosial terbagi dalam beberapa jenis, yaitu: social networks (jejaring sosial), media sosial untuk bersosialisasi dan berinteraksi seperti facebook; discuss media, media sosial yang memfasilitasi obrolan; share, media sosial yang memfasilitasi untuk saling berbagi file, video, music, dll.; publish, seperti blog; social game; MMO; virtual world; livecast; livestream; dan micro blog.

Media sosial memungkinkan seseorang berkomunikasi satu sama lain dimanapun dan kapanpun, tidak peduli seberapa jauh jarak mereka, dan tidak peduli siang atau pun malam. Saat ini media sosial memiliki dampak besar pada

${ }^{7}$ Cindy Rizal Putri Paramitha, Analisis Faktor Pengaruh Promosi Berbasis Sosial Media Terhadap Keputusan Pembelian Pelanggal dalam Bidang Kuliner, Tesis, Fak. Ekonomi UNDIP, Semarang, 2011, hlm. 17. 


\section{Al-Hikmah: Jurnal Dakwah, Volume 12, Nomar I, Tahun 2018 \\ [P. IDI-116]}

kehidupan di zaman modern. Seseorang yang asalnya "kecil" bisa seketika menjadi besar dengan media sosial, begitupun sebaliknya orang "besar" dalam sedetik bisa menjadi "kecil" dengan media sosial.

Gagasan McLuhan yang mengatakan bahwa "The medium is the message", merupakan terbukanya pintu dalam perkembangan teknologi termasuk di dalamnya adalah media sosial. Media sosial menjadi bagian dari perkembangan itu. Media dipandang sebagai perluasan dari alat indra manusia, telepon merupakan perpanjangan telinga dan televisi adalah perpanjangan mata. Maka, dengan menggunakan media sosial manusia seperti saling berkomunikasi secara langsung.

Perkembangan media sosial saat ini tidak luput dari kecanggihan mobilephone. Bahkan, mobilephone berupa smartphone menjadi kebutuhan pokok dalam berinteraksi satu sama lainnya, baik untuk urusan pekerjaan, berdiskusi, dan sebagainya. Untuk mengakses media sosial pun murah dibandingkan dengan media elektronik, cetak, dan sejenisnya. Pengguna media sosial dapat mengaksesnya meski dengan jaringan internet yang koneksinya lambat.

\section{Milenial}

Milenial adalah sebutan satu generasi berdasarkan demografi dan disebut juga generasi Y. Mereka terlahir pada saat revolusi teknologi informasi dan komunikasi serta jumlah populasinya yang cukup besar, yaitu sekira 34 persen dari penduduk Indonesia. Umumnya, generasi mileniallahir dalam rentang tahun 1981 sampai 1994. Dengan demikian generasi ini adalah mereka yang berumur 15 hingga 35 tahun. Generasi ini sudah mengenal teknologi seperti komputer, video games, smartphone, dan ketergantungan dengan internet.

Generasi ini dikenal sangat ketergantungan dengan internat, senang menghabiskan hidupnya di jejaring media daring, dan selalu mengikuti perkembangan teknologi informasi dan komunikasi dalam rangka pemanfaatan teknologi mutakhir untuk memudahkan aktivitas sehari-hari. Generasi ini melihat dunia, tidak secara langsung melainkan mereka berselancar di dunia maya. Mulai dari berkomunikasi, berbelanja online dan mendapatkan informasi dan kegiatan lainnya. Banyak dari kalangan millennial melakukan semua komunikasi melalui text messaging atau chatting dunia maya dengan membuat akun media sosial seperti twitter, facebook, line dan sebagainya.

\section{Tantangan Dakwah}

Berdakwah di era milenial berhadapan dengan pesatnya perkembangan teknologi. 
Dakwah harus menyesuaikan diri dengan perkembangan perangkat yang terus berkembang pesat. Juga, dituntut dapat diakses dengan cepat dengan konten menarik dalam bentuk digital. Terlebih pada era milenial yang kecenderungannya bergantung pada internet, aktivitas seharihari cenderung menggunakan media modern. Maka kajian tentang era milenial secara khusus penting dikaji untuk mengetahui pendekatan dakwah seperti apa yang bisa digunakan untuk mencapai kesuksesan dalam berdakwah.

Generasi milenial (sebutan generasi berdasarkan demografi dan disebut juga generasi Y) menjadi perbincangan hangat karena terlahir pada saat revolusi teknologi informasi dan komunikasi serta jumlah populasinya yang cukup besar, yaitu sekira 34 persen dari penduduk Indonesia. Umumnya, generasi milenial lahir dalam rentang tahun 1981 sampai 1994. Dengan demikian generasi ini adalah mereka yang berumur 15 hingga 35 tahun.Generasi ini sudah mengenal teknologi seperti komputer, video games, dan smartphone.

Beberapa studi tentang generasi milenial menggambarkan mereka yang terkatagori milenial dalam berkomunikasi banyak menggunakan teknologi komunikasi instan seperti email, SMS, instant messaging dan media sosial seperti facebook, line, path, instagram, whatsapp, dantwitter. Mereka juga suka main gameonline.Generasi ini dikenal sangat senang menghabiskan hidupnya di jejaring media daring. Generasi ini melihat dunia tidak secara langsung melainkan hidup di dunia maya. Mulai dari berkomunikasi, berbelanja online, mendapatkan informasi, dan kegiatan lainnya.

Inilah tantangan sekaligus peluang dakwah yang harus dieksekusi. Untuk itu,ada dua hal yang dapat dilakukan. Pertama, terkait dengan penggunaan media dakwah. Pada era digital saat ini, gadget dan media sosial tidak lepas dari generasimilenial. Maka, gadget dan media sosial harus dijadikan wasilah dakwah. Pesan dakwah harus dikemas melalui konten-konten yang akrab dengan generasi kekinian. Penggunaan portal dakwah dengan konten tidak selalu berupa tulisan, namun juga dapat dikemas dalam bentuk vlog, soundcloud, infografis, dan juga meme, dimuat di YouTube agar dakwah makin meluas. Dakwah juga dapat dilakukan secara online dengan memanfaatkan YouTube, Instagram, dan sebagainya, sebelum akhirnya bisa fenomenal secara offline. Kedua, pengemasan pesan-pesan dakwah harus menarik. Sebab, sebaik apapun materi dakwah tanpa didukung dengan kemasan yang menarik terkadang ditinggalkan orang. Dengan dua pendekatan tersebut 
[P. IDI-116]

tantangan dakwah pada generasi milenal dapat dilalui dan diselesaikan dengan baik.

\section{Perkembangan Teknologi Informasi dan}

\section{Komunikasi}

Teknologi Informasi adalahsuatu teknologi komunikasi yang digunakan untuk mengolah data, termasuk memproses, mendapatkan, menyusun, menyimpan, memanipulasi data dengan berbagai cara untuk menghasilkan informasi yang berkualitas, yaitu informasi yang relevan, akurat dan tepat waktu, yang digunakan untuk keperluan pribadi, pendidikan, bisnis, dan pemerintahan. Informasi merupakan hal yang strategis untuk pengambilan keputusan. Teknologi ini menggunakan seperangkat komputer untuk mengolah data, sistem jaringan untuk menghubungkan satu komputer dengan komputer yang lainnya sesuai dengan kebutuhan, dan teknologi telekomunikasi digunakan agar data dapat disebar dan diakses secara global. Peran yang dapat diberikan oleh aplikasi teknologi informasi dan komunikasi ini adalah untuk mendapatkan informasi bagi kehidupan pribadi seperti informasi tentang kesehatan, hobi, rekreasi, dan rohani. Sarana kerjasama antara pribadi atau kelompok yang satu dengan pribadi atau kelompok yang lainnya tanpa mengenal batas jarak dan waktu, negara, ras, kelas ekonomi, ideologi atau faktor lainnya yang dapat menghambat pertukaran pikiran.

Perkembangan teknologi informasi dan komunikasi memacu suatu cara baru dalam kehidupan, dimulai dari lahir sampai dengan berakhir, kehidupan seperti ini dikenal dengan e-life, artinya kehidupan ini sudah dipengaruhi oleh berbagai kebutuhan secara elektronik.

Perkembangan teknologi pada media massa merupakan salah satu pokok bahasan yang saling berkaitan. Membahas mengenai media massa Light, Keller dan Clahoun, mengemukakan bahwa media massa - yang terdiri atas media cetak (surat kabar, majalah) maupun elektronik (radio, televisi, film, dan internet) - merupakan bentuk komunikasi yang menjangkau sejumlah besar orang. Media massa diindentifikasikan sebagai suatu agen sosialisasi yang berpengaruh pula terhadap prilaku khalayaknya. Peningkatan teknologi yang memungkinkan peningkatan kulitas pesan serta peningkatan frekuensi penerpaan masyarakat pun memberi peluang bagi media massa untuk berpesan sebagai agen sosialisasi yang semakin penting.

\section{Peran Media dalam Dakwah}

Media berperan dalam sampainya pesan setidaknya dalam empat hal, yaitu efektivitas, efisiensi, konkret, dan 
motivatif. Media mempermudah penyampaian informasi, sebagai sarana untuk mempercepat sampainya informasi, membantu mempercepat isi pesan yang sifatnya abstrak, dan media juga dapat memotivasi penggunanya melakukan aktivitas komunikasi dibandingkan dengan komunikasi tidak bermedia. Adapun penggunaan media dalam Islam bertujuan untuk mempermudah penyampaian pesanpesan agama supaya sampai kepada masyarakat luas lebih cepat secara bersamaan, melalui media komunikasi modern hal tersebut bisa dicapai lebih banyak dari pada komunikasi yang tidak bermedia (teknologi). Sementara itu, media bisa berperan dalam pembinaan umat, penyerapan ajaran Islam bisa dengan mudah diperoleh, kemudian bisa merubah tingkah-laku pemeluknya. Pembentukan pandangan hidup dan karakter Islam bisa dihubungkan dengan peran media komunikasi. ${ }^{8}$

Dengan memaksimalkan media komunikasi dalam berdakwah, maka pesannya akan lebih cepat diterima oleh banyak orang. Mengingat jarak yang terlalu luas, tidak mungkin dapat dijangkau secara keseluruhan dengan menggunakan komunikasi langsung. Selain itu, pesan-

\footnotetext{
${ }^{8}$ Taufiq, Sistem Informasi Manajemen Konsep Dasar, Analisis, dan Metode Pengembangan, Graha Ilmu, Yogyakarta, 2013, hlm. 170.
}

pesan dakwah yang hendak disampaikan akan lebih cepat diterima. Tidak hanya itu, dakwah bermedia akan terlihat lebih menarik karena kecenderungan banyak orang yang menyukai perangkat teknologinya seperti ponsel cerdas. Belum lagi tingginya kebutuhan akan informasi yang telah membuat ketergantungan dengan perangkat media. Maka dengan beberapa alasan tersebut, media sangat berperan dalam kegiatan penyampaian pesan dalam komunikasi. Dengan mengoptimalkan penggunaannya akan memaksimalkan kegiatan dakwah. apalagi jika ditinjau dengan teori media influence, bahwa media dapat memberikan pengaruh kepada individu secara langsung ataupun tidak langsung.

\section{Trend Pengguna Internet dan Media Sosial}

Pengguna internet di Indonesia meningkat signifikan setiap tahun. KOMPAS.Com (19/02) merilis hasil survai dari Asosiasi Penyelenggara Jasa Internet Indonesia (APJII) merilis bahwa jumlah pengguna internet di Indonesia tahun 2017 mencapai 143,26 juta jiwa atau 54,68 persen dari total populasi Indonesia yang berjumlah 262 juta orang. Meningkat dibandingkan tahun 2016 yang mencapai 132,7 juta orang. Berdasarkan data tersebut, menarik pula dikaitkan dengan hasil survei CSIS 
[P. IDI-116]

sebanyak $81,7 \%$ milenial memiliki Facebook, 70,3\% memiliki Whatsapp, $54,7 \%$ memiliki Instagram. Twitter sudah mulai ditinggalkan milenial, hanya $23,7 \%$ yang masih sering mengaksesnya. ${ }^{9}$

Berdasarkan data tersebut terlihat kecenderungan masrayakat saat ini cenderung banyak yang menggunakan internet. Kemudian dari penggunaan internet tersebut, sebagian besar menggunakan aplikasi media sosial. Pesatnya perkembangan media sosial kini dikarenakan semua orang bisa memiliki media sendiri. Jika untuk memiliki media konvensional seperti televisi, radio, atau koran dibutuhkan modal yang besar dan tenaga kerja yang banyak, maka lain halnya dengan media sosial. Seorang pengguna media sosial bisa mengakses menggunakan media sosial dengan jaringan internet bahkan yang aksesnya lambat sekalipun, tanpa biaya besar, tanpa alat mahal dan dilakukan sendiri tanpa bantuan orang lain. Pengguna media sosial dengan bebas bisa mengedit, menambahkan, memodifikasi baik tulisan, gambar, video, grafis, dan berbagai model content lainnya.

${ }^{9}$ Asosiasi Penyelenggara Jasa Internet Indonesia (APJII), “Tahun 2017, Pengguna Internet di Indonesia Mencapai 143,26 Juta Orang”, diakses dari: https://ekonomi.kompas.com/read/2018/02/19/161115126/tahun-2017-pengguna-internet-di-indonesia-mencapai-14326-juta-orang, pada 1 Oktober 2018 pukul 13.25 .
Keunggulan Internet Sebagai Media

\section{Dakwah}

Kelebihan internet dibanding media lainnya untuk memudahkan proses dakwah, yaitu: pertama, tidak terhalang oleh ruang dan waktu. Dakwah melalui internet dapat diakses di mana saja, oleh siapa saja, dan kapan saja. Kedua, dakwah menjadi lebih variatif. Dakwah tidak lagi disampaikan dengan cara konvensional, Kehadiran cyber memberikan banyak cara untuk menyampaikan pesan-pesan dakwah. Selain tulisan, materidakwah bisa dalam bentuk gambar, audio,e-book(buku elektronik) ataupun video, sehingga objek dakwah dapat memilih bentuk media yang disukai. Ketiga, jumlah pengguna internet semakin meningkat. Pertumbuhan pengguna internet yang selalu meningkat merupakan kabar baikbagi para da ${ }^{e} i$ yang akan berdakwah di dunia maya, karena objek dakwah pun semakin meningkat. Keempat, hemat biaya dan energi. Dengan menyajikan materi dakwah di internet, objek dakwah tidak perlu datang ke narasumber dan membeli buku untuk menjawab masalah yang dihadapi. Sehingga bisa membantu saudara kita agar tidak mengeluarkan biaya dan tenaga 
ekstra guna memperoleh informasi yang mereka cari. $^{10}$

Dengan demikian, strategi yang dilakukan dalam kegiatan membangun jaringan dakwah adalah dengan memanfaatkan perkembangan global connection. Sistem ini merupakan salah satu alternatif untuk dijadikan sebagai wasilah untuk berdakwah. Aspek keuntungan yang diperoleh dengan pemanfaatan jaringaninternet ini antara lain dapat mempererat jalinan persaudaraan antara satu dengan lainnya juga dapat memberikan informasi dalam waktu yang singkat (aspek sosial), dapat berdiskusi mengenai perkembangan Islam (aspek agama) serta pengembangan ilmu pengetahuan dan teknologi.

Melalui internet, pesan dakwah dapat dengan mudah diakses oleh siapa saja sehingga manfaatnya dirasakan banyak orang. Maka, sesungguhnya internet menjadi media terbaik untuk menjangkau mad'u secara global, mengirimkan pesan ke lebih banyak pengguna, dengan biaya yang murah dan mampu mengomunikasikan informasi dalam waktu singkat. Banyaknya pengguna media sosial menjadi peluang meningkatkan jumlah penyerap pesandakwah.

\footnotetext{
${ }^{10}$ Pardianto, Meneguhkan Dakwah Melalui New Media, Jurnal Komunikasi Islam, ISSN 20886314, Volume 03, Nomor 01, Juni 2013, hlm. 7.
}

\section{Trend Masyarakat dalam Memilih \\ Media Komunikasi}

Jenis media yang cenderung disukai adalah media yang mendukung efektivitas dan efisiensi. Jika ditelaah mengapa seseorang jarang menonton televisi dan lebih banyak menghabiskan waktu memainkan gadgetnya, jawabannya adalah karena lebih fleksibel dari sisi waktu dan tempat.

Dengan adanya media komunikasi, maka komunikasi dapat dilakukan secara efektif. Keefektifan inilah yang dimanfaatkan baik komunikator maupun komunikan dalam melakukan hubungan komunikasi. Karena media komunikasi sendiri merupakan sarana atau alat yang memudahkan dalam menyampaikan suatu pesan atau informasi kepada komunikan sebagai penerima pesan. Itulah sebabnya kenapa media komunikasi memiliki fungsi yang efektif dalam proses komunikasi.Hal ini dapat dibuktikan bahwa adanya kemudahan seorang komunikator seperti presiden katakanlah yang menyampaikan pesan atau yang berperan sebagai komunikator ini ingin menyampaikan suatu informasi kepada masyarakat atau rakyatnya yang berperan sebagai komunikan si penerima pesan. Dengan adanya media komunikasi seperti televisi, radio, maupun media cetak seperti majalah, maka pesan dari Presiden pun dapat disampaikan dengan cepat dan mudah. 
[P. IDI-116]

Dalam melakukan sesuatu diperlukan efisiensi agar berjalan dengan efisien dan lancar, sehingga aktivitas dapat dijalankan tanpa memakan banyak waktu. Sama halnya dengan proses komunikasi yang juga membutuhkan efisiensi waktu agar proses komunikasi dapat berjalan cepat. Maka, media komunikasi inilah yang berperan besar dalam proses komunikasi untuk mempersingkat waktu dan membuat se-efisien mungkin. Dengan kata lain, fungsi kedua dari media komunikasi adalah sebagai sarana dalam mempercepat isi pesan atau informasi sampai kepada komunikan si penerima pesan atau informasi.

\section{Memaksimalkan Video Dakwah di} Youtube

Media sosial menawarkan multimedia berupa gambar, video, maupun desain yang disebarluaskan ke pengguna lainnya dan salah satu contohnya adalah YouTube. YouTube adalah penyedia layanan video terbesar saat ini dan merupakan media untuk upload secara gratis. Para pengguna dapat memuat, menonton, dan berbagi klip video secara gratis. YouTube juga sangat cocok bagi yang ingin mencari informasi tanpa harus membaca artikel. Pada umumnya video-video di YouTube adalah video klip, acara TV, film serta video buatan para penggunanya sendiri.
Manfaat lain dari penggunaan YouTube adalah bahwa isinya dapat disiarkan kepada jutaan pemirsa. YouTube tersedia di hampir setiap negara di dunia dan di setiap komputer yang memiliki akses internet, serta dikunjungi setiap hari oleh jutaan orang.

YouTube merupakan tempat filesharing bagi semua membernya di mana kita bisa mencari atau upload video rekaman kita untuk dapat di saksikan oleh orang lain. Dalam konteks dakwah, kebutuhan publik akan video durasi pendek dalam rangka menjawab kebutuhannya sangat tinggi. Beberapa fakta menunjukkan banyaknya media mania yang menonton youtube.

\section{Komunikasi Viral: Replikasi Konten Dakwah}

Konten atau pesan dakwah harus diviralkan. Viraljika dikaitkan dengan komunikasi dapat bermakna proses komunikasi yang secara berantai memperbanyak diri. Konsep kerjanya seperti berkembangbiaknya virus, yaitu memperbanyak (mereplikasi) dirinya. Strategi viral dahulu terjadi dari orang perorang, tersebar dari mulut ke mulut. Kini, dengan perkembangan media yang sangat canggih, viral terjadi di ruang-ruang media sosial dalam pergaulan di dunia maya, misalnya dengan berkicau di twiter, menyebarkan tautan berita, video, dan 
sebagainya. Viral di media semacam ini sangat memungkinkan konten dakwah dapat menyebar dengan cepat. Menyebarkan konten dakwah melalui media tidak cukup dengan melakukan viral saja. Namun, juga harus mengetahui traffic yang ramai dan pas untuk menyebarkannya. Tanpa mengetahui dan menyesuaikan dengan waktu kebanyakan orang mengakses sebuah media, maka pesan tidak sampai kepada banyak orang.

\section{Mengemas Pesan Dakwah}

Pesan adalah seperangkat lambang bermakna yang disampaikan oleh komunikator. ${ }^{11}$ Pesan adalah apa yang dikomunikasikan oleh sumber kepada penerima yang merupakan seperangkat simbol verbal atau non verbal dan mewakili perasaan, nilai, gagasan atau maksud sumber tadi ${ }^{12}$ Pesan dalam komunikasi bermedia menjadi faktor penting untuk mencapai tujuan komunikasi. Pesan dakwah harus dikemas semenarik mungkin agar memiliki daya tarik sehingga dapat diterima dengan baik oleh mad'u.

Pesan mempunyai tiga komponen, yaitu makna, simbol yangdigunakan untuk

\footnotetext{
${ }^{11}$ Onong Uchjana Effendy, Ilmu, Teori, dan Filsafat Komunikasi, Citra Aditya Bakti, Bandung, 2003, hlm. 5.

${ }^{12}$ Deddy Mulyana, Ilmu Komunikasi Suatu Pengantar, Remaja Rosdakarya, Bandung, 2005, hlm. 20.
}

menyampaikan makna, dan bentuk atau organisasipesan. Simbol terpenting adalah kata-kata (bahasa), yang dapat mempresentasikan obyek (benda), gagasan, dan perasaan, baik ucapan (percakapan, wawancara, diskusi, ceramah, dan sebagainya). Pesan juga dapat dirumuskan secara nonverbal, seperti melalui tindakan atauisyarat anggota tubuh (acungan jempol, anggukan kepala, senyuman,tatap muka, dan sebagainya), juga melalui musik, lukisan, tarian, film, dan sebagainya. Menyampaian pesan dapat pula melalui lisan, tatap muka, langsung atau menggunakan media/saluran. ${ }^{13}$

Selain komponen, pesan juga memiliki sifat khusus, yaitu bersifat informatif, persuasif, dan koersif. Pesan bersifat informatif karena hanya memberikan informasi. Dalam situasi tertentu, pesaninformatif lebih berhasil dari pada pesan persuasif. Pesan persuasif berisi bujukan yang membangkitkan pengertian dan kesadaran seseorang. Sedangkan pesan koersif bersifat memaksa. Bentuk yang terkenaldari penyampaian pesan koersif adalah agitasi, yakni denganpenekanan-penekanan yang menimbulkan penekanan batin dan ketakutan di antara sesama kalangan publik. Pesan koersif dapat

${ }^{13}$ Widjaja, Ilmu Komunikasi Pengantar Studi, Rineka Cipta, Jakarta, 2000, hlm. 14. 
[P. IDI-116]

berbentukperintah, intruksi dan sebagainya.

Beberapa konsep pesan di atas dapat menjadi acuan dalam mengemas pesan dakwah. Jika dikombinasikan, maka mengemasnya dapat dilakukan dengan berbagai cara, antara lain sebagaimana yang dikemukakan Wilson yaitu dengan memerhatikan dimensi-dimensi abstraksi pesan, kesesuaian pendengar, jenis-jenis perancangan strategi pesan untuk mencapai tujuan tertentu atau untuk mengoordinasikan berbagai macam tujuan, jenis-jenis tema isi pesan, pemilihan katakata yang khusus, dan lain-lain. ${ }^{14}$ Maka, agar pesan dapat diterima dengan baik oleh komunikan (penerima pesan), maka pesan komunikasi yang terdiri dari isi pesan dan lambang harus diproduksi dengan sangat hati-hati.

\section{KESIMPULAN}

Pendekatan dakwah kini tidak lagi cukup dengan cara-cara konvensional. Perkembangan teknologi yang kian cepat menuntut penyesuaian. Dakwah harus lebih optimal disampaikan lewat media sosial, karena generasi milenial lebih cenderung menggunakan aplikasi-aplikasi yang sifatnya interaktif, seperti whatsap. Karena itu, da'i disarankan untuk memanfaatkan

\footnotetext{
${ }^{14}$ Bangun Wilson, Manajemen Sumber Daya Manusia, Erlangga, Jakarta, 2012, hlm. 56.
}

media sosial semaksimal mungkin dalam rangka menjangkau mad'u yang lebih luas sehingga pesan dakwah terserap lebih banyak.

\section{DAFTAR PUSTAKA}

Andi Abdul Muis. 2001. Komunikasi Islami. Bandung: Remaja Rosdakarya.

Arifin. 1997. Psikologi Dakwah Islam. Jakarta: Bumi Aksara.

Cindy Rizal Putri Paramitha. 2011. Analisis Faktor Pengaruh Promosi Berbasis Sosial Media Terhadap Keputusan Pembelian Pelanggal dalam Bidang Kuliner. Thesis. Semarang: Fak. Ekonomi UNDIP.

Danis Puntoadi. 2011. Menciptakan Penjualan Melalui Sosial Media. Jakarta: ElexKomputindo.

Deddy Mulyana. 2005. Ilmu Komunikasi Suatu Pengantar. Bandung: Remaja Rosdakarya.

Lister, Martin. 2003. New Media: A Critical Introduction. London: Routledge.

M. Aminudin Sanwar. 1985. Pengantar Studi Ilmu Dakwah. Semarang: Fakultas Dakwah IAIN Walisongo.

M. Arifin. 1997. Psikologi Dakwah Suatu Pengantar.Jakarta. Bumi Aksara.

Moh. Ali Azis. 2004. Ilmu Dakwah. Edisi pertama. Jakarta: Kencana.

Onong Uchjana Effendy. 2003. Ilmu, Teori dan Filsafat Komunikasi. Bandung: Citra Aditya Bakti.

Pardianto. 2013. Meneguhkan Dakwah Melalui New Media. Jurnal: Komunikasi Islam, ISBN 20886314, Volume 03, Nomor 01, Juni 2013. 
Siti Muriah. 2000. Metodologi Dakwah Kontemporer. Yogyakarta: Mitra Pustaka.

Taufiq. 2013. Sistem Informasi Manajemen

Konsep Dasar, Analisis dan Metode Pengembangan. Yogyakarta: Graha Ilmu.

Widjaja, HAW. 2000. Ilmu Komunikasi Pengantar Studi. Jakarta: Rineka Cipta.

Wilson Bangun. 2012. Manajemen Sumber Daya Manusia. Jakarta. Erlangga. 